\title{
Development of a Rapid Risk and Impact Assessment Tool to Enhance Response to Environmental Emergencies in the Early Stages of a Disaster: A Tool Developed by the European Multiple Environmental Threats Emergency NETwork (EMETNET) Project
}

\author{
Emma-Jane Goode ${ }^{1} \cdot$ Eirian Thomas $^{1} \cdot$ Owen Landeg $^{1} \cdot$ Raquel Duarte-Davidson $^{1} \cdot$ \\ Lisbeth Hall $^{2} \cdot$ Jolanda Roelofs $^{2} \cdot$ Sjors Schulpen $^{2} \cdot$ Arnout De Bruin $^{2}$ • \\ Elisabeth Wigenstam ${ }^{3} \cdot$ Birgitta Liljedahl $^{3} \cdot$ Annica Waleij $^{3} \cdot$ Louise Simonsson $^{3}$. \\ Ann Göransson Nyberg ${ }^{3}$
}

Accepted: 21 April 2021 / Published online: 3 June 2021

(C) The Author(s) 2021

\begin{abstract}
Every year, numerous environmental disasters and emergencies occur across the globe with far-reaching impacts on human health and the environment. The ability to rapidly assess an environmental emergency to mitigate potential risks and impacts is paramount. However, collating the necessary evidence in the early stages of an emergency to conduct a robust risk assessment is a major challenge. This article presents a methodology developed to help assess the risks and impacts during the early stages of such incidents, primarily to support the European Union Civil Protection Mechanism but also the wider global community in the response to environmental emergencies. An online rapid risk and impact assessment tool has also been developed to promote enhanced collaboration between experts who are working remotely, considering the impact of a disaster on the environment and public health in the short, medium, and long terms. The methodology developed can support the appropriate selection of experts and assets to be deployed to affected regions to ensure that potential public health and environmental risks and impacts are mitigated whenever possible.
\end{abstract}

Emma-Jane Goode

Emma-jane.goode@phe.gov.uk

1 Centre for Radiation, Chemicals and Environment, Public Health England (PHE), Harwell Campus, Didcot OX11 ORQ, UK

2 Centre for Environmental Safety and Security, National Institute for Public Health and the Environment (RIVM), Bilthoven 3721 MA, The Netherlands

3 Division of CBRN Defence and Security, Swedish Defense Research Agency (FOI), 90182 Umeå, Sweden
This methodology will aid defensible decision making, communication, planning, and risk management, and presents a harmonized understanding of the associated impacts of an environmental emergency.

Keywords Civil protection - Environmental emergencies - Impact assessment - Risk assessment $\cdot$ Systematic expert judgment

\section{Introduction}

Every year, countries and regions around the world are faced with numerous natural and human-made hazards, disasters, and emergencies. In 2015, there were 353 global disaster events, of which 198 were natural catastrophes, the highest ever recorded in one year (Bevere et al. 2016). In 2017, insured losses from natural and human-made hazards and disasters across the globe were the highest recorded in a single year (Bevere et al. 2018). One study showed that more than half of the economic losses resulted from "secondary" hazards, events that may occur as direct or indirect results of the initial hazard (Bevere 2019).

The impacts of natural hazards seen globally appear to be on an upwards trend and are likely to continue as the links between climate change and extreme weather events are becoming more apparent (Forzieri et al. 2017). Rising global temperatures may lead to more frequent extreme weather events and further secondary hazards such as landslides and wildfires (Bevere and Gloor 2020). This is likely to result in larger impacts both on mortality and morbidity and economic losses (Bevere and Gloor 2020). 
Opportunities exist to reduce the public health and environmental risks and impacts from natural and humanmade hazards and disasters at all phases of a disaster life cycle-preparedness, response, recovery, and mitigation/ prevention phases (Fig. 1) (Wisner and Adams 2002). The preparedness and planning phases present a major opportunity for countries and communities to learn from previous disasters, to exercise disaster plans, and to reduce the potential impact of a disaster on the community, as well as to analyze the effectiveness of mitigation strategies and implement lessons learned post-disaster (Wisner and Adams 2002).

During an environmental emergency-defined as the "sudden onset of a disaster or an accident as a result of natural, technological or human-induced factors that cause, or threaten to cause, severe environmental damage" (JEU 2009, p. 8) - actions taken during the response phase can significantly influence the duration and magnitude of such risks and impacts (Wisner and Adams 2002). Focusing on the initial response phase of a disaster, knowing the potential public health and environmental risks and impacts that may exist at such a pivotal time can significantly impact the outcome of response actions (Wisner and Adams 2002). By rapidly analyzing the risks and impacts in this early phase, response strategies can be targeted and prioritized to mitigate these as far as possible.

The European Union (EU) co-funded the European Multiple Environmental Threats emergency NETwork (EMETNET) project, which sought to develop and share a more efficient and rapid public health and environmental risk/impact assessment methodology, for use at the European level, primarily to support the European Union Civil Protection Mechanism (EUCPM) (European Parliament and Council 2013) and at the global community level to support the response to natural hazard-related and humanmade disasters (Hall et al. 2017).

A methodology was developed that contains a rapid risk and impact assessment template, and a supporting guidance document. An online assessment tool was developed to promote enhanced remote analysis and collaborative work.

The methodology and tool were developed to support and strengthen interdisciplinary collaboration in response to environmental emergencies. They enable the required expertise and information to be elicited from a multidisciplinary network of expert risk assessors across the field of disaster response and management. Such a networkwhich can gather virtually using collaborative software (Hall et al. 2017)_removes geographical barriers for international response to supporting countries that are facing an environmental emergency in its early phase.

The outputs from the tool developed can be used to inform decision making at the earliest point by targeting and prioritizing risk and impact mitigation strategies to reduce the potential impacts to health and the environment (Hall et al. 2017). This tool facilitates the selection of experts and assets to be deployed to affected regions and provides a snapshot assessment to experts on the way to disaster zones. They may be used to aid defensible decision making, communication, planning, and risk management. Other risk and impact tools currently consider either health or the environment, while this rapid risk assessment (RRA) and impact assessment tool considers both health and environment together. This tool supports a harmonized understanding of the associated health, environmental, and cross-sectoral impacts of an environmental emergency (Hall et al. 2017). This article describes the risk and impact
Fig. 1 Disaster life cycle and opportunities to mitigate risk. Source Adapted from Wisner and Adams (2002)

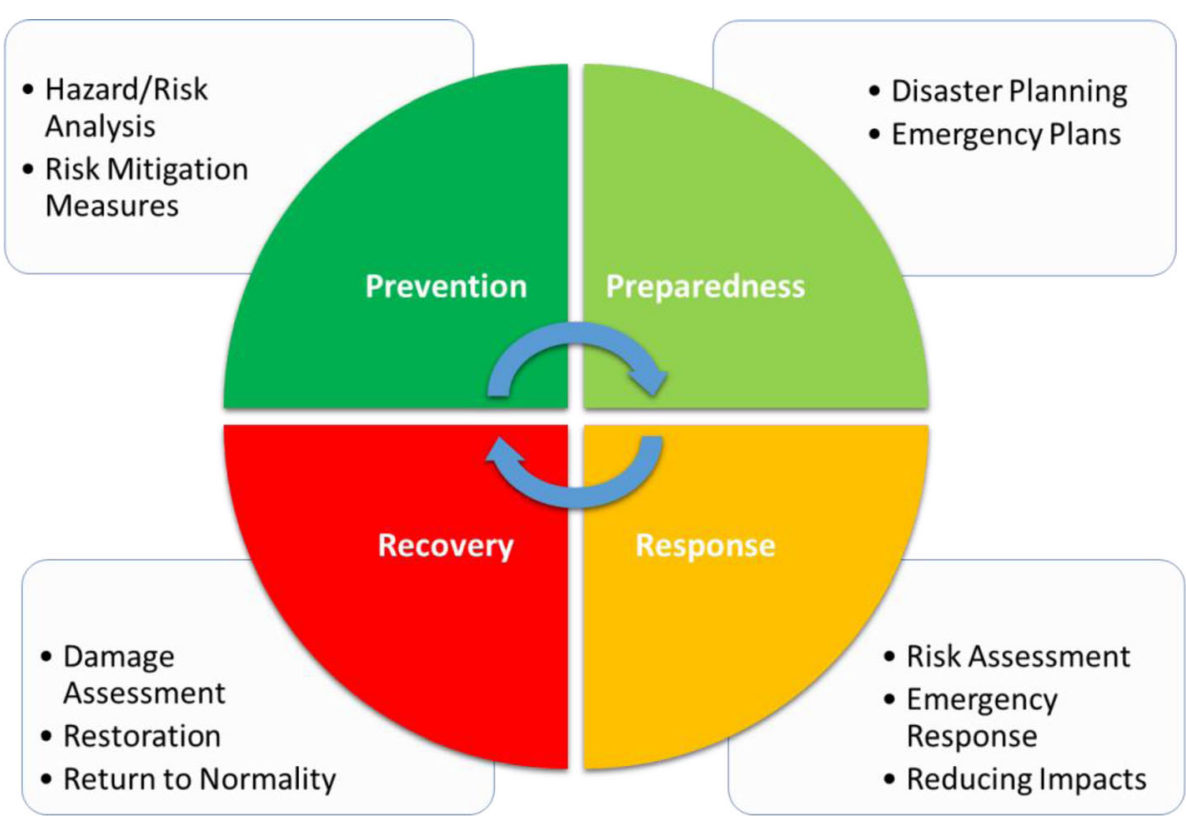


assessment tools that, in collaboration with a network of expert risk assessors, could be used to inform decision making at the earliest opportunity.

\section{Rapid Risk Assessment (RRA)}

A RRA is a quick and prompt assessment of risks normally undertaken within 24-48 h of an incident (WHO 2012). Rapid risk assessments rely on information available in the early stages of an incident and/or emerging event. This information is often limited and/or quickly changing and can be based largely on expert opinion. Rapid risk assessments therefore can carry greater risk of uncertainty and limitation (WHO 2012; Goode, Collins et al. 2018). However, they are a vital means of informing the immediate response to an incident, including the implementation of control measures to reduce risk and impact (WHO 2012; Goode, Collins et al. 2018). The RRA should ideally be a comprehensive template that contains several sections for information to be reported and recorded, essentially acting as a checklist to risk assessors to ensure that all the relevant information is captured, including the reasons for drawing certain conclusions (SCHEER 2017; Goode, Collins et al. 2018).

\subsection{Development of the Methodology}

A rapid risk assessment methodology was developed to provide a harmonized approach across the EU for the response to environmental emergencies, which focuses on the risks to public health and the environment (Hall et al. 2017). The methodology was based on a rapid risk assessment methodology developed by the European Chemical Emergency Network (ECHEMNET) to support the implementation of the EU Decision (1082/2013/EU) (EC 2013) on serious cross-border threats to health (SCHEER 2017) and to assist with the response to a serious cross-border threat to health associated with a chemical agent or environmental event in the EU (SCHEER 2017).

During development of the methodology, a scoping assessment was carried out to determine which hazards would be considered when assessing public health and environmental risks. Working from a list of the biggest disaster risks to the EU (EC 2017), hazards were included within the assessment based on whether they were already considered by other EU or international agencies-for example, the European Centre for Disease Control (ECDC) - or whether they were within scope (that is, likely to cause an environmental emergency). This is summarized in Table 1.

Biological or radiological incidents were not within the scope as they were already considered by other EU agencies, but they have been included within the RRA methodology to highlight the possibility of these incidents occurring as a result of a natural hazard. Such incidents can often be referred to as natural hazards triggering technological accidents (NaTech accidents). The Fukushima nuclear accident, for example, was triggered by an earthquake and a tsunami. During these incidents, there is a need to ensure that experts notify/engage with the appropriate agencies, such as the ECDC and the European Atomic Energy Community (Euratom).

With respect to chemical incidents that have occurred because of a natural hazard-for example, the 2017 Arkema Plant Explosion in Texas as a result of Hurricane Harvey-the RRA methodology can broadly assess the risks to health and the environment. However, should a rapid assessment of the health risks from chemicals be required, the experts may want to refer to national methodologies and/or templates as well as methodologies already available elsewhere that specifically focus on chemicals, such as the World Health Organization (WHO) RRA for acute public health events methodology (WHO 2012), or the Joint UNEP/OCHA Environment Unit Flash Environmental Assessment Tool (FEAT) (JEU 2016), or the methodology used by the European Commission that was specifically developed to deal with incidents involving chemical cross-border health threats (EC 2013).

During the scoping assessment, it was noted that natural hazards do not necessarily happen in isolation, and therefore consequential or secondary hazards must also be considered. A cyclonic storm, for example, is likely to cause widespread flooding, environmental pollution, and, in some cases, landslides. Each of these consequential hazards can create new risks and should be considered within the public health and environmental risk assessment or, where practical, a separate RRA should be carried out for each one. When designing the risk assessment template, both primary (causal) and secondary (consequential) hazards were considered, as well as the individual exposures to each hazard, to ensure that all aspects of an environmental emergency are accounted for.

Once the scope of the risk assessment had been determined, selected case studies were used to help develop the structure of the RRA methodology. The list of selected events is shown in Table 2. Where possible, information obtained on each event $24-48 \mathrm{~h}$ after it occurred was used to test the RRA methodology. Through this process, it was determined that a comprehensive guidance document would need to be developed alongside the RRA template to signpost disaster-specific considerations to the expert risk assessor.

Throughout the development of the RRA methodology, it was continually tested in a series of workshops and exercises attended by experts in the field to ensure that it 
Table 1 List of the biggest disaster risks to the EU and whether they are within scope

\begin{tabular}{|c|c|}
\hline Type of hazard & Inclusion? \\
\hline $\begin{array}{l}\text { Chemical, Biological, Radiological and Nuclear } \\
\text { (CBRN) events (intentional) }\end{array}$ & No-outside of scope, likely to be dealt with by police/defence agencies \\
\hline Cyber attacks & $\begin{array}{l}\text { No- outside of scope, unlikely to cause an environmental emergency, likely to be dealt with } \\
\text { by different agencies }\end{array}$ \\
\hline Droughts & Yes \\
\hline Earthquakes & Yes \\
\hline Environmental pollution & $\begin{array}{l}\text { Yes—as a consequential, downstream hazard after an environmental or chemical disaster/ } \\
\text { incident }\end{array}$ \\
\hline Floods & Yes \\
\hline Harmful organisms & Yes \\
\hline Industrial accidents & $\begin{array}{l}\text { Yes, technological disasters and major accidents (not biological or radiological in nature) } \\
\text { that may result in harm to the population or environment. For chemical incidents, the } \\
\text { RRA can assess risks to population and environment although chemical-specific RRAs } \\
\text { should be conducted as well by appropriate agencies }\end{array}$ \\
\hline Landslides & Yes \\
\hline Livestock epidemics & No, outside of scope \\
\hline Loss of critical infrastructure & $\begin{array}{l}\text { No, although impact of this will be considered within risk assessment in the event of an } \\
\text { environmental emergency }\end{array}$ \\
\hline Marine/coastal pollution & $\begin{array}{l}\text { Yes—as a consequential, downstream hazard after an environmental or chemical disaster/ } \\
\text { incident }\end{array}$ \\
\hline Nuclear/radiological accidents & No-likely to be dealt with by appropriate EU agencies \\
\hline Pandemics/epidemics & No-likely to be dealt with by appropriate EU agencies (for example, the ECDC) \\
\hline Public disorder & No--outside of scope as likely to be dealt with by other agencies (for example, police) \\
\hline Refugees/unmanaged migration & $\begin{array}{l}\text { No-outside of scope, likely to be dealt with by other agencies (for example, border control } \\
\text { agencies) }\end{array}$ \\
\hline Severe weather & Yes \\
\hline Space weather & Yes \\
\hline Terrorist attacks & No- - outside of scope, likely to be dealt with by security/defence agencies \\
\hline Transport accidents & Yes, if likely to result in harm to the population or environment \\
\hline Tsunamis & Yes \\
\hline Volcanic eruptions & Yes \\
\hline Water/food contamination & $\begin{array}{l}\text { Yes—as a consequential, downstream hazard after an environmental or chemical disaster/ } \\
\text { incident }\end{array}$ \\
\hline Wild/Forest fires & Yes \\
\hline
\end{tabular}

was suitable for its intended use. Stakeholders and end users gave considerable feedback to allow for further refinement of the structure of the RRA template.

\subsection{Rapid Risk Assessment Tool}

The RRA tool comprises a RRA template to record data, observations, and expert opinions, and characterizes the risks and impacts of the hazard(s); and a guidance document that contains information to assist expert risk assessors in completing the template. Each of the nine sections within the RRA template is designed to collate all the available information pertinent to the event and inform an assessment summary. A description of each section is outlined in Table 3.

The accompanying guidance document provides an overview of each section in the template along with several points for experts to consider. The guidance document also details the roles and tasks of the ad hoc expert working group that would be rapidly set up and charged with undertaking the RRA. Finally, a glossary of key terms is included to standardize terminology throughout the RRA process. 
Table 2 Selected case studies used to help develop the structure of the rapid risk assessment methodology

\begin{tabular}{|c|c|}
\hline Hazard & Real-life events \\
\hline Storm & $\begin{array}{l}2010 \text { Cyclone Xynthia } \\
2012 \text { Hurricane Sandy } \\
2013 \text { Typhoon Haiyan/Super Typhoon } \\
\text { Yolanda }\end{array}$ \\
\hline Flood & $\begin{array}{l}\text { 2013/2014 UK Winter Floods } \\
2014 \text { Kashmir Floods }\end{array}$ \\
\hline Earthquakes & $\begin{array}{l}2010 \text { Haiti Earthquake } \\
2016 \text { Ecuador Earthquake }\end{array}$ \\
\hline Extreme temperatures & $\begin{array}{l}2010 \text { Northern Hemisphere Summer } \\
\text { Heatwaves } \\
2014 \text { North American Cold wave }\end{array}$ \\
\hline Droughts & $\begin{array}{l}2010 \text { China Drought and Dust Storms } \\
2011 \text { East African Drought }\end{array}$ \\
\hline Landslides & $\begin{array}{l}2002 \text { Kolka-Karmadon Rock Ice Slide } \\
2015 \text { Columbian Landslides }\end{array}$ \\
\hline Tsunami & $\begin{array}{l}2004 \text { Boxing Day Tsunami } \\
2010 \text { Sumatra Earthquake and Tsunami } \\
2011 \text { Tōhoku Earthquake and Tsunami }\end{array}$ \\
\hline $\begin{array}{l}\text { Technological } \\
\text { disasters and } \\
\text { major accidents }\end{array}$ & $\begin{array}{l}2012 \text { Talvivaara Mining Gypsum Pond Leak } \\
2015 \text { Bento Rodrigues Dam Disaster }\end{array}$ \\
\hline Wildfires & $\begin{array}{l}2010 \text { Russian Wildfires } \\
2016 \text { Fort McMurray Wildfire }\end{array}$ \\
\hline Volcanic activity & $\begin{array}{l}2002 \text { Mount Nyiragongo Eruption (Congo) } \\
2010 \text { Eruptions of Eyjafjallajökull (Iceland) }\end{array}$ \\
\hline Harmful organisms & $\begin{array}{l}2009 \text { French Algal Blooms } \\
2013 \text { Madagascar Locust Infestation } \\
2016 \text { Florida Algal Bloom }\end{array}$ \\
\hline $\begin{array}{l}\text { Extra-terrestrial } \\
\text { impacts }\end{array}$ & $\begin{array}{l}2007 \text { Carancas Impact Event } \\
2013 \text { Chelyabinsk Meteor Impact }\end{array}$ \\
\hline $\begin{array}{l}\text { Environmental } \\
\text { pollution }\end{array}$ & $\begin{array}{l}2006 \text { Southeast Asian Haze } \\
2010 \text { Deepwater Horizon Oil Spill }\end{array}$ \\
\hline Space weather & $\begin{array}{l}1989 \text { Geomagnetic Storm } \\
2003 \text { Halloween Solar Storms }\end{array}$ \\
\hline
\end{tabular}

\subsection{Rapid Remote Disaster Analysis}

A pilot expert risk assessor network was developed in conjunction with the RRA tools (Hall et al. 2017). In the event of an environmental emergency, an ad hoc expert working group, a subset of the risk assessor network, can be tasked to work remotely yet collaboratively, using digital tools, to carry out a public health and environmental rapid risk and impact assessment. The ad hoc working group would consist of a chairperson to lead the working group, secretariat to manage the flow of information, and expert risk assessors with expertise specific to the emergency and environment-for example, climatologists for weather-related events (Hall et al. 2017).

The RRA template is available as an online tool to promote efficient collaborative work as well as streamlining the version control process (Fig. 2). Behind the RRA template is a database that allows previous RRAs to be stored. This means that in the event of an incident, previous RRAs on similar incidents can be recalled and used to further inform current or new RRAs. This tool allows multiple users to work on one risk assessment at the same time, reducing the amount of time required to complete the risk assessment. The tool delivers better version control, with previous versions stored within the database. The digital tool was tested during a workshop and an exercise in October 2017 and received positive feedback from project stakeholders on its ability to improve collaborative work.

\section{Impact Assessment}

The impact assessment tool allows risk managers to quickly identify where the highest risks and impacts are, by allowing managers to compare the public health and environmental impacts of natural hazard-related and human-made disasters with the estimated risks (from the rapid risk assessment) (Hall et al. 2017). This allows for a more tailored approach to risk and impact management, and ensures that the response is commensurate with the impacts.

\subsection{Impact Assessment Development}

Three potential indices were identified to ensure that the impact scale could be used in conjunction with the risk assessment methodology:

- Health impact

- Environmental impact

- Cross-sectoral and social impact

Grouping the potential impacts into indices allows the impact assessment to be represented visually. Previous scales, such as the European Scale for Industrial Accidents scale (IMPEL 2013), have utilized visual scales to help users identify the biggest impacts quickly.

One of the objectives of the impact assessment was to ensure a harmonized approach across the EU. When determining what parameters would be suitable for categorizing impact, several impact or consequence parameters used within the EU were examined. The EU report, "Overview of Natural and Man-made Disaster Risks the European Union May Face," details the specific natural hazard-related and human-made disaster risks that face the individual member states and the EU as whole (EC 2017). 
Table 3 Rapid risk assessment methodology-overview of the sections

\begin{tabular}{|c|c|c|}
\hline Section title & Purpose & What is included \\
\hline $\begin{array}{l}\text { Rapid Risk } \\
\text { Assessment } \\
\text { Summary }\end{array}$ & $\begin{array}{l}\text { To provide a concise summary of the } \\
\text { assessment and risks }\end{array}$ & $\begin{array}{l}\text { Key conclusions and concerns } \\
\text { Key updates } \\
\text { Impact assessment summary }\end{array}$ \\
\hline Event Control Data & $\begin{array}{l}\text { To summarize the key information of the } \\
\text { incident }\end{array}$ & $\begin{array}{l}\text { Time and date of occurrence } \\
\text { Critical risk questions } \\
\text { Summary of the event } \\
\text { Key points of contact for risk assessors (both within appropriate EU/NGO } \\
\text { organizations and local points of contact) }\end{array}$ \\
\hline Hazard Assessment & $\begin{array}{l}\text { To provide information on the key points and } \\
\text { features of the hazard(s) that have caused the } \\
\text { incident }\end{array}$ & $\begin{array}{l}\text { This assessment considers both causal incidents (the initial incident) and } \\
\text { actual or potential consequential incidents (incidents that occur as a } \\
\text { secondary effect of the initial incident) } \\
\text { Type of hazards } \\
\text { Hazard summary } \\
\text { Location details }\end{array}$ \\
\hline $\begin{array}{l}\text { Exposure } \\
\text { Assessment }\end{array}$ & $\begin{array}{l}\text { Evaluation of the exposure of the individuals, } \\
\text { populations, and environments to the hazards } \\
\text { identified in the Hazard Assessment Section }\end{array}$ & $\begin{array}{l}\text { Exposed population details } \\
\text { Exposed environment details } \\
\text { Maps and geographical information, where relevant } \\
\text { Potential for cross-border spread } \\
\text { Identification of vulnerable groups }\end{array}$ \\
\hline Health Assessment & $\begin{array}{l}\text { Evaluation of current morbidity and mortality } \\
\text { data, trauma care-related needs, and the } \\
\text { wider public health impact of the } \\
\text { hazard(s) on the population }\end{array}$ & $\begin{array}{l}\text { Morbidity, mortality, and missing people data } \\
\text { Population demographics } \\
\text { Identification of vulnerable groups } \\
\text { Clinical management } \\
\text { Local health care facilities } \\
\text { Impact on air, drinking water, food, sanitation } \\
\text { Likelihood of communicable disease }\end{array}$ \\
\hline $\begin{array}{l}\text { Environmental } \\
\text { Assessment }\end{array}$ & $\begin{array}{l}\text { Evaluation of the risks and impacts of the } \\
\text { incident(s) on the environment including air, } \\
\text { water, land and soil, vegetation, biodiversity, } \\
\text { protected areas, and ecosystem services }\end{array}$ & $\begin{array}{l}\text { Relevant environmental assessment tools such as the Flash } \\
\text { Environmental Assessment Tool (FEAT), the Rapid Environmental } \\
\text { Impact Assessment in Disasters (REA) tool, and the Post Disaster Needs } \\
\text { Assessment (PDNA) tool are considered in this section } \\
\text { Air quality and atmosphere } \\
\text { Natural waters } \\
\text { Land and soil } \\
\text { Flora and fauna } \\
\text { Agriculture, crops, and managed land } \\
\text { Landscape, aesthetics, and noise } \\
\text { Waste management } \\
\text { Remediation }\end{array}$ \\
\hline $\begin{array}{l}\text { Social and Cross- } \\
\text { Sectoral } \\
\text { Observations }\end{array}$ & $\begin{array}{l}\text { This section presents information available } \\
\text { on the potential risks and impacts on society } \\
\text { and different sectors that may have an impact } \\
\text { on health and the environment }\end{array}$ & $\begin{array}{l}\text { It is important to note that this section is not intended to assess/evaluate } \\
\text { the impacts of the incident on social, religious, and political matters on } \\
\text { society or to pass judgment, but rather to provide a platform to record } \\
\text { observations on these issues/sectors, which may have a further effect on } \\
\text { the health and environmental risks identified in the earlier sections or may } \\
\text { increase exposure to these identified risks } \\
\text { Country's ability to respond to such an incident (for example, have } \\
\text { response agencies been affected) } \\
\text { Energy and communications infrastructure } \\
\text { Police, military, and security services } \\
\text { Transport infrastructure and border control } \\
\text { Services within the local communities } \\
\text { Rehousing and educational facilities }\end{array}$ \\
\hline
\end{tabular}


Table 3 continued

\begin{tabular}{lll}
\hline Section title & Purpose & What is included \\
\hline Impact Assessment & $\begin{array}{l}\text { Compares the public health, environmental, } \\
\text { and cross-sectoral impacts of the incident }\end{array}$ & $\begin{array}{l}\text { The Impact Assessment is a simple color-coded assessment that } \\
\text { graphically represents the potential impacts for each index to allow risk } \\
\text { managers to quickly identify where the highest risks are }\end{array}$ \\
$\begin{array}{ll}\text { Overall Risk } \\
\text { Characterization }\end{array}$ & $\begin{array}{l}\text { The risks and impacts are brought together } \\
\text { and ranked to estimate the overall } \\
\text { consequences or impacts of the assessment }\end{array}$ & $\begin{array}{l}\text { Determine the overall level of risk } \\
\text { Determine the overall level of confidence in the risk assessment }\end{array}$ \\
\hline
\end{tabular}

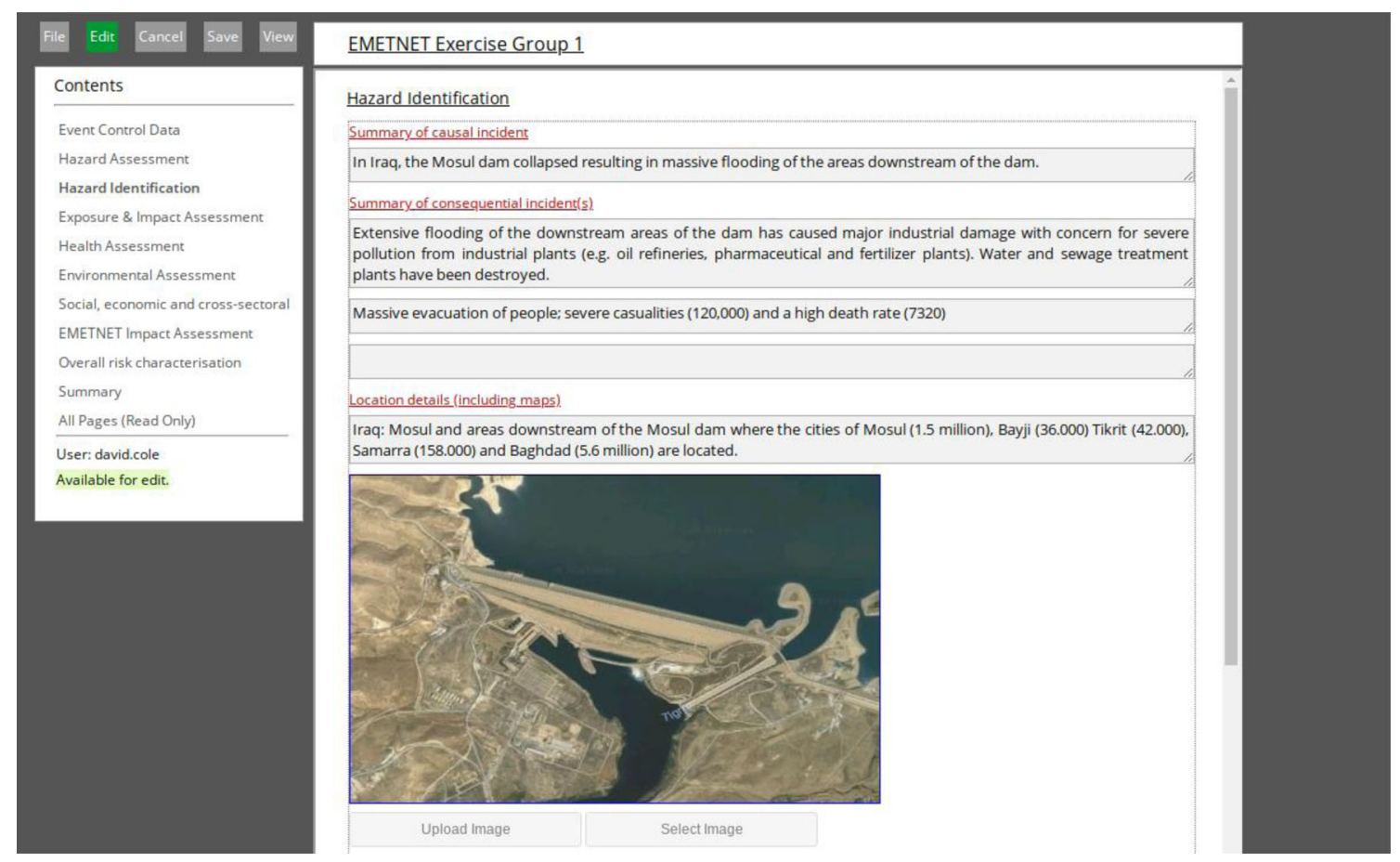

Fig. 2 Digital rapid risk assessment tool

For this report, national risk assessments (NRAs) and impact assessments for disaster risks were carried out by the member states. Each impact assessment contained a number of levels or parameters that were reviewed and compared with the EMETNET, ECHEMNET, and WHO RRA methodologies (Hall et al. 2017; SCHEER 2017; Goode, Collins et al. 2018). To ensure a harmonized approach, the number of characterization levels in the risk and impact assessments was considered, as was the common terminology used. Five levels of characterization were most commonly used by the majority of countries. Looking at the terminology for impact and risk characterization levels in the NRAs, level 1 and level 5 showed the most consistent language throughout the EU member states. Level 1 is most often referred to as "insignificant" and level 5 is most often referred to as "catastrophic." There is less consistent terminology across levels 2,3 , and 4, but in most cases two or three terms are often the most popular; level 2-low/minor/substantial, level 3-moderate/serious, and level 4-significant/very serious/major (EC 2017).

From reviewing this terminology - and from continuous stakeholder feedback throughout the project (for example, workshops and exercises) (Goode, Thomas et al. 2018; Hall et al. 2018)-the terminology for the impact assessment parameters was chosen as follows: (1) Insignificant; (2) Minor; (3) Moderate; (4) Major; (5) Catastrophic.

Discussions with stakeholders and expert risk assessors concluded that the range of disasters covered by this impact assessment made it a challenge to use quantitative measures to define each level. Quantitative data would need to be considered within the context of the disaster-for example, 25 people killed in a wildfire may be considered a high mortality rate, whereas 25 people killed in an earthquake may be considered to be a low mortality rate. Accurate information and/or data may also not be readily available at such an early juncture after the incident, when 
Table 4 Impact assessment criteria for each level of each index; health, environment, and cross-sectoral

\begin{tabular}{|c|c|c|c|}
\hline Severity & Health & Environmental & Cross-Sectoral \\
\hline \multirow[t]{9}{*}{ Insignificant } & Very limited impact on health: & $\begin{array}{l}\text { No to occasional impact on non-significant } \\
\text { environmental/ecological receptors }\end{array}$ & $\begin{array}{l}\text { No to limited disruption to normal } \\
\text { activities and services, which does not } \\
\text { impact on daily life }\end{array}$ \\
\hline & - No to low mortality & $\begin{array}{l}\text { The impact on the environment is } \\
\text { temporary and quickly self-repaired with } \\
\text { no resource input. No long-term effects } \\
\text { expected on the environment }\end{array}$ & No impact on infrastructure \\
\hline & $\begin{array}{l}\text { - No to low morbidity; mild transient } \\
\text { adverse health effects or symptoms }\end{array}$ & $\begin{array}{l}\text { Unlikely to have an impact on air, water, } \\
\text { or land quality }\end{array}$ & $\begin{array}{l}\text { No to limited extra costs for authorities } \\
\text { and stakeholders, and no impact on or loss } \\
\text { of livelihoods }\end{array}$ \\
\hline & Very limited exposure to hazard & $\begin{array}{l}\text { Unlikely to result in waste that requires } \\
\text { special disposal procedures }\end{array}$ & $\begin{array}{l}\text { Country response capabilities are not } \\
\text { affected }\end{array}$ \\
\hline & $\begin{array}{l}\text { No to low numbers of missing and affected } \\
\text { (health) people }\end{array}$ & No remedial action required & \\
\hline & $\begin{array}{l}\text { Identified vulnerable groups are unlikely to } \\
\text { be affected }\end{array}$ & & \\
\hline & $\begin{array}{l}\text { Unlikely to be an additional burden on } \\
\text { local health care facilities }\end{array}$ & & \\
\hline & $\begin{array}{l}\text { Unlikely to cause additional public health } \\
\text { burden or need additional public health } \\
\text { control measures }\end{array}$ & & \\
\hline & $\begin{array}{l}\text { Unlikely to have an impact on air quality, } \\
\text { drinking water, food safety and security, } \\
\text { and sanitation services }\end{array}$ & & \\
\hline \multirow[t]{10}{*}{ Minor } & Minor impact on health: & $\begin{array}{l}\text { Occasional and infrequent impact on non- } \\
\text { significant environmental/ecological } \\
\text { receptors }\end{array}$ & $\begin{array}{l}\text { Limited disruption to normal activities and } \\
\text { services, which may impact on daily life } \\
\text { for a short period of time }\end{array}$ \\
\hline & - Low mortality & $\begin{array}{l}\text { The impact is temporary and reversible } \\
\text { without resource input, but additional time } \\
\text { may be required to return to normal. } \\
\text { Unlikely to result in long-term effects on } \\
\text { the environment }\end{array}$ & $\begin{array}{l}\text { Occasional and infrequent impacts on non- } \\
\text { critical infrastructure }\end{array}$ \\
\hline & $\begin{array}{l}\text { - Low morbidity; mild transient adverse } \\
\text { health effects or symptoms }\end{array}$ & $\begin{array}{l}\text { Potential for a transient impact on air, } \\
\text { water, or land quality }\end{array}$ & The impact is local only \\
\hline & $\begin{array}{l}\text { A small population or at-risk group may } \\
\text { have exposure to the hazard }\end{array}$ & $\begin{array}{l}\text { Potential for a limited amount of waste } \\
\text { that may require special disposal } \\
\text { procedures }\end{array}$ & $\begin{array}{l}\text { Minor increase in costs for authorities and } \\
\text { stakeholders. Limited and occasional } \\
\text { impact on livelihoods }\end{array}$ \\
\hline & $\begin{array}{l}\text { Less than } 50 \% \text { of the local population may } \\
\text { be affected }\end{array}$ & $\begin{array}{l}\text { May require limited remedial action but is } \\
\text { not time-critical. Remedial action is } \\
\text { unlikely to have further environmental } \\
\text { impact }\end{array}$ & $\begin{array}{l}\text { Country response capabilities are unlikely } \\
\text { to be affected }\end{array}$ \\
\hline & $\begin{array}{l}\text { Potential for low numbers of missing } \\
\text { people }\end{array}$ & & \\
\hline & $\begin{array}{l}\text { A limited number of identified vulnerable } \\
\text { groups have the potential to be affected }\end{array}$ & & \\
\hline & $\begin{array}{l}\text { Limited and infrequent additional burden } \\
\text { on local health care facilities }\end{array}$ & & \\
\hline & $\begin{array}{l}\text { May cause short-term limited public health } \\
\text { burden and/or require a few additional } \\
\text { public health control measures }\end{array}$ & & \\
\hline & $\begin{array}{l}\text { Limited and infrequent impact on air } \\
\text { quality, drinking water, food safety and } \\
\text { security, and sanitation services }\end{array}$ & & \\
\hline
\end{tabular}


Table 4 continued

\begin{tabular}{lll}
\hline Severity & Health & Environmental \\
\hline Moderate & Moderate impact on health: & $\begin{array}{l}\text { Occasional and infrequent impact on } \\
\text { significant environmental/ecological } \\
\text { receptors }\end{array}$ \\
$\qquad$ Notable mortality & $\begin{array}{l}\text { The impact on the environment is } \\
\text { sustained and cannot be reversed without } \\
\text { additional resource input. Potential for } \\
\text { limited long-term effects on the } \\
\text { environment }\end{array}$
\end{tabular}

- Notable morbidity; sustained adverse health effects or symptoms and potential for reduced life quality and/or expectancy A medium sized population and/or a few at-risk groups are likely to have exposure to the hazard

At least $50 \%$ of the local population is likely to be affected

Likely to be a significant number of missing people

Identified vulnerable groups are likely to be affected

Additional burden on local health care facilities that is likely to require some extra resources

Significant but short-term public health burden and/or is likely to require additional public health control measures

Temporary impact to air quality, drinking water, food safety and security, or sanitation services unlikely to last longer than a few weeks

Major Major impact on health:

- High mortality

- High morbidity; serious and potentially irreversible adverse health effects, reduced life quality and/or expectancy

A large population and at-risk groups have exposure to the hazard

Up to $75 \%$ of the local population is likely to be affected
There is a transient impact on air, water, or land quality

Is likely to result in waste that requires special disposal procedures

Will require remedial action with some actions being time-critical. There is a potential for remedial action to have further impact on the environment

Several environmental/ecological receptors can be affected (flora, fauna, not without significance to the local/regional population)

Some especially sensitive/valuable receptors can be affected

The impact on the environment is sustained and cannot be reversed without a significant input of resources. Is likely to result in long-term and sustained effects on

Significant and potentially sustained impact on air, water, or land quality

Will result in a significant amount of waste that requires special disposal procedures and may, in some instances, cause further impact on the environment the environment
Cross-Sectoral

Moderate disruption to normal activities and services, which is likely to have significant impact on daily life in the short to medium term

Significant impact to non-critical infrastructure and/or occasional and infrequent impact to critical infrastructure

The impact can only under exceptional circumstances affect a geographic area larger than "local"

Moderate increase in costs for authorities and stakeholders. Sustained impact on livelihoods with the potential for loss of livelihoods in certain industries

The incident is unlikely to impact or cause conflict

Country response capabilities are likely to be slightly affected
Major disruption to normal activities and services, which will have a significant and sustained impact on daily life

Significant and potentially sustained impacts to critical infrastructure

The impact can, under certain circumstances, spread to a larger geographic area

The incident could, under certain circumstances, impact or cause conflict

Significant increase in costs for authorities and stakeholders with the potential to require financial aid. Significant and sustained impact on and loss of livelihoods in several industries, including some that are vital to the economy 
Table 4 continued

\begin{tabular}{|c|c|c|c|}
\hline Severity & Health & Environmental & Cross-Sectoral \\
\hline & Significant numbers of missing people & $\begin{array}{l}\text { Will require significant time-critical } \\
\text { remedial action that can have further } \\
\text { impact on the environment }\end{array}$ & $\begin{array}{l}\text { Country response capabilities may be } \\
\text { badly affected with the potential to require } \\
\text { international assistance }\end{array}$ \\
\hline & $\begin{array}{l}\text { Identified vulnerable groups are } \\
\text { significantly affected }\end{array}$ & & \\
\hline & $\begin{array}{l}\text { Significant additional burden on local and } \\
\text { neighboring health care facilities that } \\
\text { require a considerable amount of extra } \\
\text { resources and/or loss of local health care } \\
\text { facilities }\end{array}$ & & \\
\hline & $\begin{array}{l}\text { Medium to long-term public health burden } \\
\text { and/or will require many additional public } \\
\text { health control measures }\end{array}$ & & \\
\hline & $\begin{array}{l}\text { Sustained impacts to air quality, drinking } \\
\text { water, food safety and security, or } \\
\text { sanitation services unlikely to last longer } \\
\text { than a few weeks }\end{array}$ & & \\
\hline \multirow[t]{10}{*}{ Catastrophic } & Severe impact on health: & $\begin{array}{l}\text { A large number of environmental/ } \\
\text { ecological receptors can be seriously } \\
\text { affected (flora, fauna, with importance to } \\
\text { the local or regional population) }\end{array}$ & $\begin{array}{l}\text { Severe disruption to normal activities and } \\
\text { services, which will have a significant and } \\
\text { sustained impact on daily life with the } \\
\text { potential to last months to years }\end{array}$ \\
\hline & - Very high mortality & $\begin{array}{l}\text { Especially sensitive/valuable receptors can } \\
\text { be seriously affected }\end{array}$ & $\begin{array}{l}\text { Severe and sustained and/or irreversible } \\
\text { impacts to critical infrastructure }\end{array}$ \\
\hline & $\begin{array}{l}\text { - Very high morbidity; irreversible and/ } \\
\text { or life threatening adverse health effects, } \\
\text { or death, significantly reduced life quality } \\
\text { and/or expectancy }\end{array}$ & $\begin{array}{l}\text { The impact on the environment is } \\
\text { permanent and irreversible with further } \\
\text { long-term effects }\end{array}$ & $\begin{array}{l}\text { A large number of additional control } \\
\text { measures will be needed and will require } \\
\text { significant resources to implement }\end{array}$ \\
\hline & $\begin{array}{l}\text { A large population and at-risk groups have } \\
\text { had significant exposure to the hazard }\end{array}$ & $\begin{array}{l}\text { Severe and sustained or permanent impact } \\
\text { on air, water, or land quality }\end{array}$ & $\begin{array}{l}\text { The impact will have a large geographic } \\
\text { distribution }\end{array}$ \\
\hline & $\begin{array}{l}\text { Most of the local population has been } \\
\text { affected }\end{array}$ & $\begin{array}{l}\text { Will result in very large amounts of waste } \\
\text { that requires special disposal procedures or } \\
\text { cannot be disposed of without causing } \\
\text { further impact on the environment }\end{array}$ & $\begin{array}{l}\text { The activity can impact or cause } \\
\text { significant conflict }\end{array}$ \\
\hline & Significant numbers of missing people & $\begin{array}{l}\text { Remedial action is required as a priority } \\
\text { and/or is likely to cause further irreversible } \\
\text { damage to the environment }\end{array}$ & $\begin{array}{l}\text { Serious increase in costs for authorities } \\
\text { and stakeholders likely to require financial } \\
\text { aid. Significant and sustained impact on } \\
\text { and loss of livelihoods in industries vital to } \\
\text { the economy }\end{array}$ \\
\hline & $\begin{array}{l}\text { Identified vulnerable groups are } \\
\text { significantly affected }\end{array}$ & & $\begin{array}{l}\text { Country response capability is } \\
\text { significantly affected and is likely to } \\
\text { require significant international assistance }\end{array}$ \\
\hline & $\begin{array}{l}\text { Loss of local health care facilities and } \\
\text { significant additional burden on } \\
\text { neighboring health care facilities requiring } \\
\text { extensive additional international } \\
\text { resources }\end{array}$ & & \\
\hline & $\begin{array}{l}\text { Long-term public health burden and/or } \\
\text { will require significant additional public } \\
\text { health control measures }\end{array}$ & & \\
\hline & $\begin{array}{l}\text { Sustained and potentially permanent } \\
\text { impacts to air quality, drinking water, food } \\
\text { safety and security, or sanitation services } \\
\text { likely to last longer than a few weeks }\end{array}$ & & \\
\hline
\end{tabular}




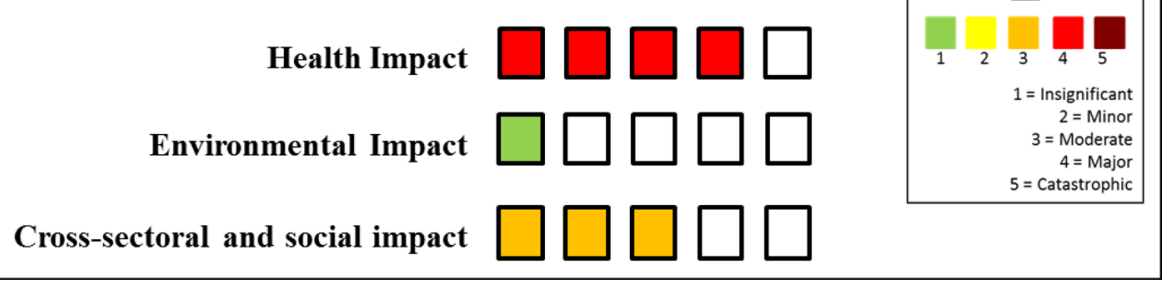

Fig. 3 The impact assessment scale. The potential health impacts, in this example, are rated as major, while the environmental impacts are rated as insignificant, and the cross-sectoral impacts are rated as

the initial RRA and impact assessment is likely to be conducted, and so applying quantitative or semi-quantitative measures may prove to be inaccurate at this early point. As this needed to be a "one-size-fits-all" approach, it was decided to develop a set of qualitative criteria for each level, to be used in conjunction with expert opinion within the context of the specific disaster. However, if appropriate data are available, they could be used to support expert opinion. The criteria for each level are listed in Table 4.

\subsection{Impact Assessment}

A simple color-coded assessment that visually shows the potential impacts for each index was developed, utilizing two methods of visualization: a color coding to show severity based on the green-amber-red style risk matrices and a number scale (1-5) to highlight the severity of the potential impacts as shown in Fig. 3.

By adding a visual illustration of the potential severity of impacts from a disaster to the summary sheet of the RRA methodology, risk managers, who are presented with this summary, will be able to quickly and easily identify which area (health, environment, cross-sectoral) is likely to experience the greatest impacts. This will allow the risk managers to tailor and prioritize risk management strategies accordingly.

\section{Next Steps}

For these risk and impact assessment tools to be used appropriately, a sustainable mechanism for use needs to be developed. The online tools and RRA template need to be hosted in an accessible digital format to ensure ease of access. Although originally designed to support the ERCC (EU Emergency Response Coordination Centre) and the EU response to environmental disasters, these tools could be made available to the international disaster response community.

Technical and specialist input is required to ensure that the risks and impacts are appropriately assessed. While a moderate. This would provide a quick visual representation of where the greatest potential impacts are likely to be; in this case, it would be health

multidisciplinary network of experts has been set up, further support is required to ensure the network is embedded into response structures. Work needs to be carried out to ensure that networks and mechanisms across the EU for all types of events-for example, natural hazards, CBRN (chemical, biological, radiological and nuclear) incidents, and so on-are harmonized and use similar approaches to risk assessment and response. A good example of where project outputs have become embedded in EU structures is the mechanism established for dealing with chemical crossborder health threats in Europe. A permanent mechanism has been established by the European Commission to get ad hoc rapid advice on chemical risks through the EU Scientific Committee on Health, Environmental and Emerging Risks (SCHEER) (SCHEER 2017). A similar mechanism for responding to risks involving natural hazard-related and human-made disasters would ensure that a sustainable system is in place within the EC to provide expert advice during environmental emergencies when requested by countries around the world.

\section{Conclusion}

The EMETNET RRA methodology and impact assessment bring added value to the field of disaster risk reduction and management by considering health and the environment together within disaster risk and impact management. Most other current RRA methodologies only consider the environment in terms of its impact on public health (Goode, Thomas et al. 2018), and tools such as the Flash Environment Assessment tool (FEAT) (JEU 2016) and the Rapid Environment Assessment (REA) (JEU 2018) tool consider the environmental impacts with limited public health consideration. The methodology presented here considers the impact of a disaster on the environment and public health in the short, medium, and long terms, as well as endeavoring to provide a harmonized approach to risk and impact assessment. The digital RRA and impact tool also enables expert risk assessors to collaborate remotely and provide back office support, thus ensuring that the 
internationally available expertise is put at the disposal of disaster-stricken countries.

Acknowledgements The European Multiple Environmental Threats emergency NETwork (EMETNET) project was co-funded by the European Union.

Open Access This article is licensed under a Creative Commons Attribution 4.0 International License, which permits use, sharing, adaptation, distribution and reproduction in any medium or format, as long as you give appropriate credit to the original author(s) and the source, provide a link to the Creative Commons licence, and indicate if changes were made. The images or other third party material in this article are included in the article's Creative Commons licence, unless indicated otherwise in a credit line to the material. If material is not included in the article's Creative Commons licence and your intended use is not permitted by statutory regulation or exceeds the permitted use, you will need to obtain permission directly from the copyright holder. To view a copy of this licence, visit http://creativecommons. org/licenses/by/4.0/.

\section{References}

Bevere, L. 2019. Secondary natural catastrophe risks on the front line. Sigma, no. 2/2019. Zurich: Swiss Re.

Bevere, L., and M. Gloor. 2020. Natural catastrophes in times of economic accumulation and climate change. Sigma, no. 2/2020. Zurich: Swiss Re.

Bevere, L., M. Schwartz Pourrabbani, and R. Sharan. 2018. Natural catastrophes and man-made disasters in 2017: A year of recordbreaking losses. Sigma, no. 1/2018. Zurich: Swiss Re.

Bevere, L., R. Sharan, and K. Vipin. 2016. Natural catastrophes and man-made disasters in 2015: Asia suffers substantial losses. Sigma, no. 1/2016. Zurich: Swiss Re.

EC (European Commission). 2013. Decision No 1082/2013/EU of the European Parliament and of the Council of 22 October 2013 on serious cross border threats to health and repealing Decision No 2119/98/EC. Official Journal of the European Union 293: 1-15. https://ec.europa.eu/health//sites/health/files/preparedness_ response/docs/decision_serious_crossborder_threats_22102013_ en.pdf. Accessed 9 Apr 2021.

EC (European Commission). 2017. Overview of natural and manmade disaster risks the European Union may face. Commission staff working document SWD, Brussels, Belgium. https://op. europa.eu/en/publication-detail/-/publication/285d038f-b54311e7-837e-01aa75ed71a1. Accessed 9 Apr 2021

European Parliament and Council. 2013. Decision No. 1313/2013/EU of the European Parliament and of the Council of 17 December 2013 on a Union Civil Protection Mechanism. Official Journal of the European Union 347: 924-927. https://eur-lex.europa.eu/ LexUriServ/LexUriServ.do?uri=OJ:L:2013:347:0924:0947:EN: PDF. Accessed 9 Apr 2021.

Forzieri, G., A. Cescatti, and F.B. e Silva, and L. Feyen. . 2017. Increasing risk over time of weather-related hazards to the
European population: A data-driven prognostic study. The Lancet Planetary Health 1(5): e200-e208.

Goode, E., S. Collins, C. Hague, R. Orford, and R. Duarte-Davidson. 2018. Rapid public health risk assessments for emerging chemical health threats. In Chemical health threats: Assessing and alerting, ed. R. Duarte-Davidson, T. Gaulton, S. Wyke, and S. Collins, 138-151. Cambridge, UK: Royal Society of Chemistry.

Goode, E., E. Thomas, O. Landeg, C. Hague, A. Bone, and R. DuarteDavidson. 2018. Work package 2: Impact assessment scale, rapid risk assessment methodology and guidance for risk assessors. Brussels, Belgium: European Multiple Environmental Threats Emergency Network (EMETNET), European Commission.

Hall, L., J. Roelofs, S. Schulpen, A. De Bruin, S. Banus, R. DuarteDavidson, E. Thomas, and E. Goode et al. 2017. Supporting the EU response to environmental emergencies: European Multiple Environmental Threats Emergency Network. International Journal of Safety and Security Engineering 7(3): 324-336.

Hall, L., S. Schulpen, J. Roelofs, A. de Bruin, and S. Banus. 2018. Work package 3: Developing a network for the rapid risk assessment of environmental emergencies. Brussels, Belgium: European Multiple Environmental Threats Emergency Network (EMETNET), European Commission.

IMPEL (European Union Network for the Implementation and Enforcement of Environmental Law). 2013. European scale of industrial accidents. https://www.aria.developpement-durable. gouv.fr/wp-content/uploads/2014/08/European-scale-of-acci dents.pdf. Accessed 9 Apr 2021.

JEU (Joint UNEP/OCHA Environment Unit). 2009. Environmental emergencies-Learning from multilateral response to disasters. New York: United Nations. https://www.unocha.org/sites/uno cha/files/EnvEm_LearningFromMultilateralResponse.pdf. Accessed 9 Apr 2021.

JEU (Joint UNEP/OCHA Environment Unit). 2016. The Flash Environmental Assessment Tool (FEAT) pocket guide V2.0. https://www.unocha.org/sites/dms/Documents/FEAT_pocket_ final.pdf. Accessed 9 Apr 2021.

JEU (Joint UNEP/OCHA Environment Unit). 2018. Guidelines for rapid environmental impact assessment in disasters. https:// reliefweb.int/sites/reliefweb.int/files/resources/REA_2018_final. pdf. Accessed 9 Apr 2021.

SCHEER (Scientific Committee on Health, Environmental and Emerging Risks). 2017. Guidance on ad hoc rapid risk assessment of serious cross-border chemical health threats performed by the Scientific Committee on Health, Environmental and Emerging Risks (SCHEER). https://ec.europa.eu/health/sites/ health/files/scientific_committees/scheer/docs/scheer_o_005.pdf. Accessed 9 Apr 2021.

WHO (World Health Organization). 2012. Rapid risk assessment of acute public health events. Geneva: World Health Organisation. http://www.who.int/csr/resources/publications/HSE_GAR_ ARO_2012_1/en/. Accessed 9 Apr 2021.

Wisner, B., and J. Adams (eds.). 2002. Environmental health in emergencies and disasters: A practical guide. Geneva: World Health Organization. https://apps.who.int/iris/handle/10665/ 42561. Accessed 9 Apr 2021. 